\title{
Correction to: Real wage growth in the U.S. health workforce and the narrowing of the gender pay gap
}

Janis Barry ${ }^{*}$ (D)

Correction to: Hum Resour Health (2021) 19:105 https://doi.org/10.1186/s12960-021-006473

Following the publication of the original article [1], the author identified typos in the article and that the incorrect Additional file 1 was published.

The original article [1] has been corrected (Additional file 1).

\section{Supplementary Information}

The online version contains supplementary material available at https://doi. org/10.1186/s12960-021-00676-y.

Additional file 1. Table S1. Summary Statistics (2001-2017)
Published online: 10 November 2021

\section{Reference}

1. Barry J. Real wage growth in the U.S. health workforce and the narrowing of the gender pay gap. Hum Resour Health. 2021;19:105. https://doi.org/ 10.1186/s12960-021-00647-3.

\section{Publisher's Note}

Springer Nature remains neutral with regard to jurisdictional claims in published maps and institutional affiliations.
The original article can be found online at https://doi.org/10.1186/s12960021-00647-3.

*Correspondence: barryfiguero@fordham.edu

Department of Economics, Fordham University, 113 West 60th Street,

New York, NY 10023, USA

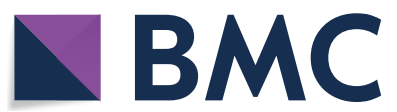

(c) The Author(s) 2021. Open Access This article is licensed under a Creative Commons Attribution 4.0 International License, which permits use, sharing, adaptation, distribution and reproduction in any medium or format, as long as you give appropriate credit to the original author(s) and the source, provide a link to the Creative Commons licence, and indicate if changes were made. The images or other third party material in this article are included in the article's Creative Commons licence, unless indicated otherwise in a credit line to the material. If material is not included in the article's Creative Commons licence and your intended use is not permitted by statutory regulation or exceeds the permitted use, you will need to obtain permission directly from the copyright holder. To view a copy of this licence, visit http://creativecommons.org/licenses/by/4.0/. The Creative Commons Public Domain Dedication waiver (http://creativeco mmons.org/publicdomain/zero/1.0/) applies to the data made available in this article, unless otherwise stated in a credit line to the data. 